\title{
The Influence of Temperature on the Absorption Capacity of Total Phosphorus by Lemna minor $\mathrm{L}$.
}

\author{
DORIAN-GABRIEL NEIDONI ${ }^{1 *}$, MIHAELA DRAGALINA ${ }^{1}$, VALERIA NICORESCU ${ }^{1}$, ALINA BANCIU ${ }^{2}$, \\ CATALINA STOICA ${ }^{2}$, MIHAI-NITA LAZAR ${ }^{2}$ \\ ${ }^{1}$ National Research and Development Institute for Industrial Ecology- ECOIND, Timisoara Subsidiary, 115 Bujorilor Str., \\ 300431, Bucharest, Romania \\ ${ }^{2}$ National Research and Development Institute for Industrial Ecology - ECOIND, 71-73 Drumul Podul Dambovitei Str., \\ 060652, Bucharest, Romania
}

\begin{abstract}
The objectives of the study were 1) to investigate the degree of pollution of phosphorus-loaded water using Lemna minor L. and 2) the absorption capacity of this organic compound by the Lemna minor $L$. aquatic plant, depending on the temperature parameter.
\end{abstract}

Keywords: Lemna minor L., temperature, total phosphorus

Compared to other aquatic plants, Lemna minor L. (duckweed) rapidly proliferates, it has a very high growth rate [1], and an excellent absorption capacity of various pollutants from water [2]. Also, duckweed can grow in a wide variety of climatic conditions and it is easier to harvest than other macrophytes [3]. Duckweed has been commonly used as a hydrophilic model in ecotoxicology studies, due to its small size, simple structure and morphology, rapid growth rate, short life span and sensitivity to pollutants [4]. In temperate and tropical areas, some duckweed species (for example, $S$. polyrhiza, L. minor, L. gibba, L. minuta) do not have vegetative rest during autumn-winter, although their growth do slow when it is colder. In this respect, they can be effectively used for wastewater treatments throughout the year [5, 6]. Floating as well as emerging plants have been studied for the removal of nutrients and heavy metals present in various types of wastewater [7-9]. In addition, the tolerance of Lemna minor L. to the high loads of organic and inorganic nutrients has been proved, so this plants are effective to remove pollutants through filtration and bioaccumulation processes [5]. Although the growth of plants (terrestrial and aquatic) occurs over a large temperature range $\left(0-50^{\circ} \mathrm{C}\right)[10]$, the absorption of nutrients is somehow conditioned and more specific to different plant species.

Phosphorus is a macronutrient essential for the growth and harmonious development of terrestrial and aquatic plants $[1,11]$, but its presence in large quantities is harmful to the environment, especially to the aquatic systems, because triggers to the eutrophication. Eutrophication is a serious environmental pollution phenomenon being a major threat to the sustainable and the development of society as well as to the survival of humanity. The rapid development of the industrial and agricultural economy discharges a large amount of industrial and agricultural wastewaters, including municipal sewerage. Most of those wastewaters have been evacuated into lakes and rivers, leading to eutrophication of aquatic systems [12]. Anthropogenic activities, especially chemical pollution, have triggered various forms of environmental change [13]. According to the OECD (World Economic Cooperation and Development Organization), 80\% of water eutrophication has been attributed to phosphorus, $10 \%$ of water bodies eutrophication directly related to nitrogen and phosphorus and the remaining $10 \%$ has been triggered by nitrogen and other factors [14]. The effects of eutrophication are numerous including, inter alia, the excessive growth of algae, the increase in the production of organic matter, which leads to the generation of hypoxic/anoxic conditions [15]. The chemical, biological and physical treatments have been very diverse based on the local regulations and level of pollutants [16].

Unfortunately, most of the pollutants have a longer life time, they are resilient into the nature and could spread over large areas and they could accumulate into aquatic organisms. The bioaccumulation factor -BCF- is expressed as the ratio between the final concentration of a chemical substance in the organism and the initial concentration of a chemical substance in water [8].

The objectives of the study were 1) to investigate the degree of pollution of phosphorus-loaded water using Lemna minor L., and 2) the absorption capacity of this organic compound by the Lemna minor L. aquatic plant, depending on the temperature parameter.

*email: ecoind.tm@gmail.com 


\section{Experimental part}

Plant material

The plant material (Lemna minor L.) was harvested from a natural pond and transferred to the laboratory. Plants were acclimatized for 7 days to laboratory conditions, at a temperature range from $19^{\circ}$ to $25^{\circ} \mathrm{C}$. The chemical composition of the water in which plants were acclimatized was very well established (table 1). Moreover, the acclimatization conditions were chosen not to influence the growth and absorption of phosphorus by plants before starting the experiments.

Table 1

THE CHARACTERISTICS OF TAP WATER

\begin{tabular}{|c|c|c|c|c|c|c|}
\hline $\mathbf{p H}$ & $\begin{array}{c}\text { Phosphorus } \\
(\mathbf{m g} / \mathbf{L})\end{array}$ & $\begin{array}{c}\text { Ammonium } \\
(\mathbf{m g} / \mathbf{L})\end{array}$ & $\begin{array}{c}\text { Nitrates } \\
(\mathbf{m g} / \mathbf{L})\end{array}$ & $\begin{array}{c}\text { Nitrites } \\
(\mathbf{m g} / \mathbf{L})\end{array}$ & $\begin{array}{c}\text { Calcium } \\
(\mathbf{m g} / \mathbf{L})\end{array}$ & $\begin{array}{c}\text { Magnesium } \\
(\mathbf{m g} / \mathbf{L})\end{array}$ \\
\hline 7.1 & 0,040 & $<0,025$ & 2.46 & $<0,024$ & 15.3 & 4.89 \\
\hline
\end{tabular}

\section{Experimental conditions}

Approximately $10 \mathrm{~g}$ of plant material were placed in $10 \mathrm{~cm}$ diameter transparent plastic containers and incubated in $250 \mathrm{~mL}$ of tap water enriched with total phosphorus (TP) up to concentrations of 4, 6, 8 and $10 \mathrm{mg} / \mathrm{L}$ (TP 4, TP 6 , TP 8 and TP 10).

The experimental time was $72 \mathrm{~h}$ at: $20^{\circ}, 25^{\circ}$ or $30^{\circ} \mathrm{C}\left( \pm 0.5^{\circ} \mathrm{C}\right)$ with a day/night cycle of $16 / 8 \mathrm{~h}$. The total amount of phosphorus was quantified after 24 and $72 \mathrm{~h}$ both in water (expressed in $\mathrm{mg} / \mathrm{L}$ ), and in plants, (expressed in $\mathrm{g} / \mathrm{kg}$ of $\mathrm{dry}$ matter), respectively. To see the behavior of the plants and after 72 hours, a 120-hour experiment was performed, at ambient temperature of $25^{\circ} \mathrm{C}$. The data for it is shown in the table 3.

\section{Methods of analysis}

Plants. About $5 \mathrm{~g}$ of wet vegetal material was mixed for 5-10 minutes with 0.5-1 $\mathrm{g}$ of animal charcoal. The sample was transferred into an Erlenmeyer flask and $50 \mathrm{~mL}$ of $2 \% \mathrm{CH}_{3} \mathrm{COOH}$ was added, incubated for 10-15 min then it was filtered. $1 \mathrm{~mL}$ of the acetic acid extract was transferred in a $25 \mathrm{~mL}$ solution containing $3 \mathrm{~mL}$ of molybdenum reagent and $1 \mathrm{~mL}$ of ascorbic acid then the sample was incubated in the dark for 15-20 minutes. The detection of total phosphorus was spectrophotometrically analyzed at $600 \mathrm{~nm}$.

Water. The determination of total phosphorus in water was performed using the Specord PC 205 spectrophotometer, Analytic Jena, according to SR EN ISO 6878: 2005.

\section{Bioaccumulation factor}

$\mathrm{BCF}=\mathrm{C}_{\text {plant }} / \mathrm{C}_{\text {water }}$

Where, $C_{\text {plant }}$ was nutrient concentrations (TP) in plant tissue, expressed in $\mathrm{mg} / \mathrm{kg}$ d.m. and $C_{\text {water }}$ is nutrient concentrations (TP) in water, expressed in $\mathrm{mg} / \mathrm{L}$. A higher BCF value implies a higher phytoaccumulation capacity [3].

\section{Results and discussions}

Lemna minor L. in phosphorus-loaded water purification

The plants were grown in presence of four phosphorus concentrations, chosen based on the most commonly TP concentration values detected in untreated wastewater.

The degree of purification of phosphorus-loaded water by Lemna minor L. was quantified after $24 \mathrm{~h}$ and $72 \mathrm{~h}$ experimental time. It was observed, a decrease of TP in water in the first 24 hours and in the next 72 regardless of the temperature intervals. The best results were achieved after 72 hours for all concentrations (TP 4, TP 6 , TP 8 and TP 10) (figs. 1, 2, 3).

The percentage of purrification yields at $20^{\circ} \mathrm{C}$ decreased during the time from the baseline to 72 hours was in the range of $31.2 \%-37.5 \%$, with a peak at $4 \mathrm{mg} / \mathrm{L}$ TP and a minimum at $8 \mathrm{mg} / \mathrm{L} \mathrm{TP}$ (fig. 1). 


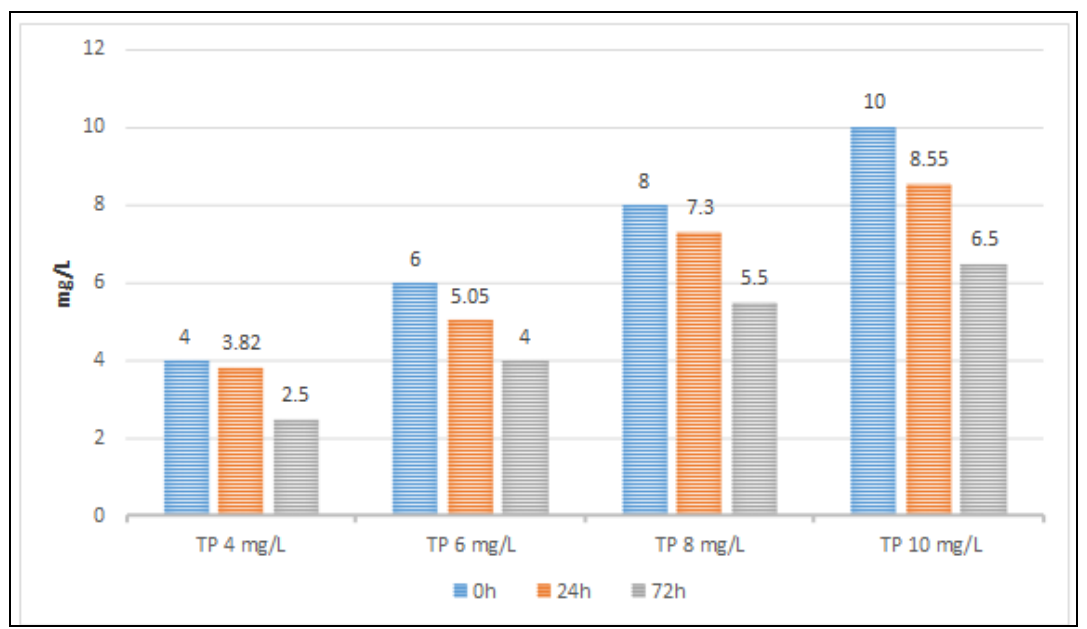

Fig. 1. Concentrations of TP in the water at $20^{\circ} \mathrm{C}$ (after 0,24 and 72 hours).

The data represents the arithmetic average value of three replicates

At $25^{\circ} \mathrm{C}$, the purification rate increased from $80 \%$ in $4 \mathrm{mg} / \mathrm{L}$ TP to $88.5 \%$ in the case of the $6 \mathrm{mg} / \mathrm{L} \mathrm{TP}$, then slightly decreased, to a minimum of $74 \%$ purification based on the initial concentration of $10 \mathrm{mg} / \mathrm{L} \mathrm{TP}$ (fig. 2).

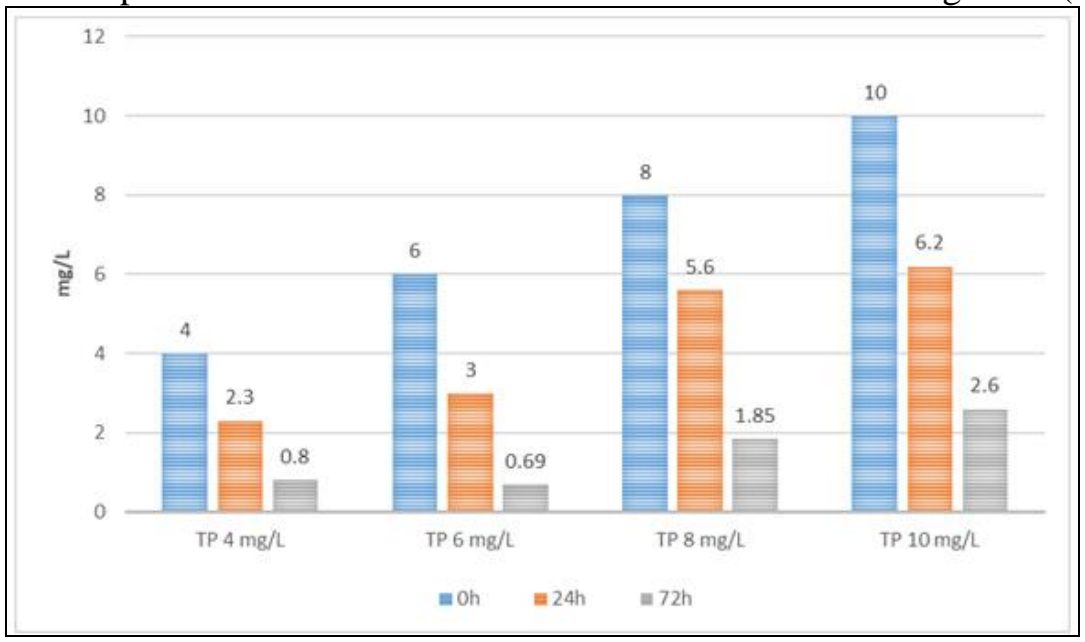

Fig. 2. Concentrations of TP in the water at $25^{\circ} \mathrm{C}$ (after 0,24 and 72 hours).

The data represents the arithmetic average value of three replicates

Figure 3 shows that, at an ambient temperature of $30^{\circ} \mathrm{C}$, the percentage of purification yields of TP in water was inversely proportional to the initial amount of TP from water: TP 4 shows a $70 \%$ decrease (from $4 \mathrm{mg} / \mathrm{L} \mathrm{to} 1.20 \mathrm{mg} / \mathrm{L}$ ) > $54.2 \%$ (from $6 \mathrm{mg} / \mathrm{L}$ to $2.75 \mathrm{mg} / \mathrm{L}$ ) TP $6>40 \%$ (from $8 \mathrm{mg} / \mathrm{L}$ to $4.80 \mathrm{mg} / \mathrm{L}$ ) TP 8 and (from $10 \mathrm{mg} / \mathrm{L}$ to $6 \mathrm{mg} / \mathrm{L}$ ) TP 10.

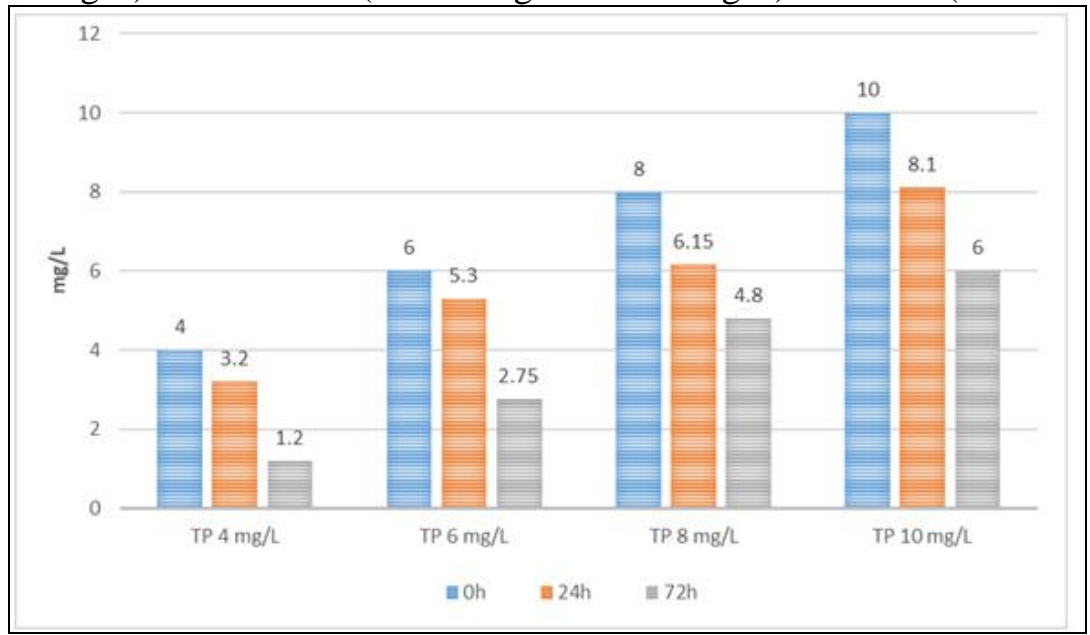

Fig. 3. Concentrations of TP in the water at $30^{\circ} \mathrm{C}$ (after 0,24 and 72 hours). The data represents the arithmetic average value of three replicates 
The purification yields obtained in our experimental sets were similar (45.5\% -73.3\%) to those obtained after 96 hours of treatment with Lemna gibba $\mathrm{L}$. in presence of $8 \mathrm{mg} / \mathrm{L}$, at a temperature range of $10^{\circ}$ to $32^{\circ} \mathrm{C}$, with a maximum at 23 degrees Celsius [6].

Our data showed the best purification yield of the organically substance loaded water by Lemna minor L. at $25^{\circ} \mathrm{C}>$ $30^{\circ} \mathrm{C}>20^{\circ} \mathrm{C}$ (figure 4 ).

These data were also backed-up by literature data, where Iatrou et al. in 2015 [17], reported that the highest growth rate of Lemna minor L., growth in diluted human urine, was observed at $24^{\circ} \mathrm{C}$. Other authors has reported the $22.5^{\circ}-27.5^{\circ}$ $\mathrm{C}$ temperature range as ideal for the development of this plant species [18]. A high plant growth rate also induced a more effective treatment of organic substances in water.

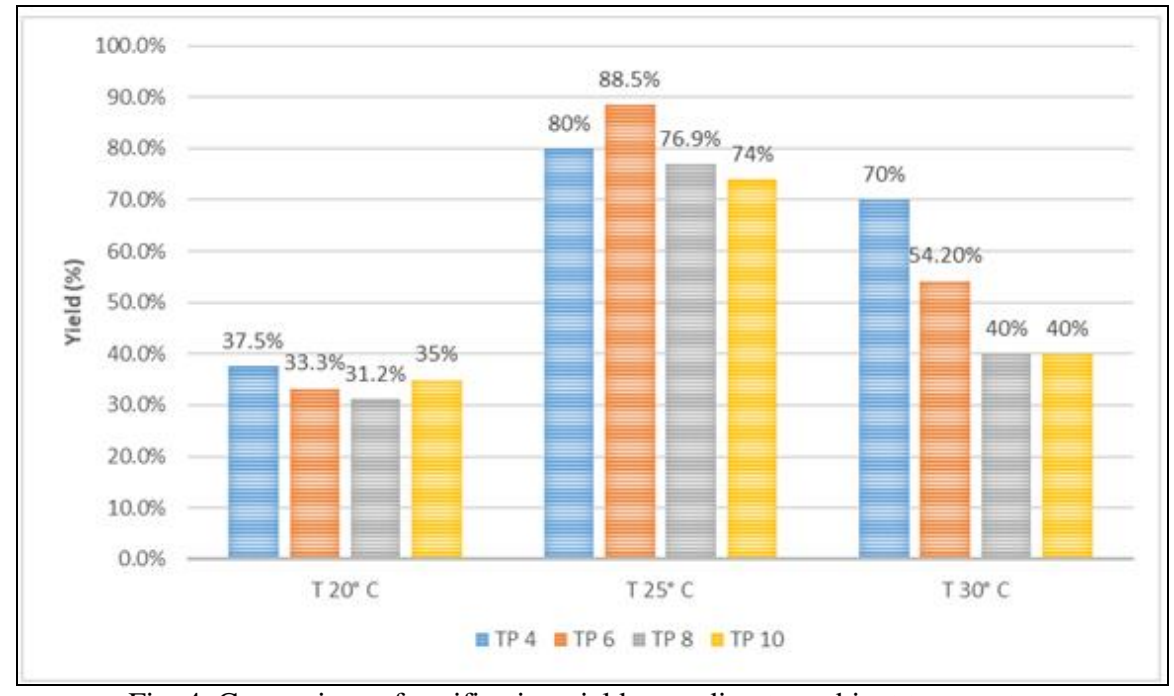

Fig. 4. Comparison of purification yield according to ambient temperature

\section{Temperature influence on TP uptake of Lemna minor L. and calculation of BCF}

In the following is presented the total amount of phosphorus absorbed by plants according to phosphorus concentration in the water.

Our data clearly showed that the phosphorus bioaccumulation capacity was modulated by the temperature (table 2 ). It can be seen that for all four experimental variants the maximum absorption of phosphorus in plants was at $25^{\circ} \mathrm{C}$ followed by a temperature of $30^{\circ} \mathrm{C}$ after 72 hours of treatment. One explanation for this might be that most terrestrial and aquatic plants prefer a medium with relatively high temperature for cellular processes, especially for photosynthesis [10].

Comparing the four experimental variants exposed at $25^{\circ} \mathrm{C}$, it appeared that TP bioaccumulation in the plant was directly proportional to the initial amount of TP in the water. It is worth mentioning the difference between TP 6 and TP 8 and TP 10 was very low, which mean that around $15 \mathrm{~g} / \mathrm{kg} \mathrm{d.m.,} \mathrm{the} \mathrm{plant} \mathrm{reached} \mathrm{saturation,} \mathrm{regardless} \mathrm{of} \mathrm{the} \mathrm{amount} \mathrm{of}$ total phosphorus in the water at the initial time.

Table 2

BIOACCUMULATION OF TOTAL PHOSPHORUS IN PLANTS EXPRESSED IN G/KG D.M.

\begin{tabular}{|c|c|c|c|c|c|c|c|c|c|}
\hline \multirow{2}{*}{$\begin{array}{c}\text { Experimental } \\
\text { variants }\end{array}$} & \multicolumn{3}{|c|}{ Temperature 20 $\mathbf{C}$} & \multicolumn{3}{|c|}{ Temperature 25$^{\circ} \mathbf{C}$} & \multicolumn{3}{|c|}{ Temperature 30$^{\circ} \mathbf{C}^{\circ}$} \\
\cline { 2 - 10 } & $\mathbf{0 ~ h}$ & $\mathbf{2 4} \mathbf{~ h}$ & $\mathbf{7 2} \mathbf{~ h}$ & $\mathbf{0 ~ h}$ & $\mathbf{2 4} \mathbf{~ h}$ & $\mathbf{7 2 ~ h}$ & $\mathbf{0 ~ h}$ & $\mathbf{2 4} \mathbf{h}$ & $\mathbf{7 2} \mathbf{~ h}$ \\
\hline TP 4 & 3.60 & 3.90 & 6.23 & 3.60 & 6.80 & 10.7 & 3.60 & 4.55 & 8.57 \\
\hline TP 6 & 3.60 & 5.02 & 7.59 & 3.60 & 7.90 & 14.6 & 3.60 & 4.90 & 10.9 \\
\hline TP 8 & 3.60 & 5.56 & 9.60 & 3.60 & 7.20 & 15.0 & 3.60 & 5.12 & 12.3 \\
\hline TP 10 & 3.60 & 7.12 & 11.1 & 3.60 & 9.25 & 15.5 & 3.60 & 8.38 & 12.4 \\
\hline
\end{tabular}

Moreover, the behavior of Lemna minor L. in the phosphorus solution was observed after $120 \mathrm{~h}$ an additional experimental test (table 3). The results showed slightly increase of phosphorus bioaccumulation in plants, which leads to the conclusion that, for a rapid and efficient treatment of total phosphorus-loaded water, the optimal treatment period can be around $72 \mathrm{~h}$, after which the plants can be harvested and renewed.

There was a large amount of nutrients in the plant body after harvesting which can be used as a nutritional supplement for animal feed [7] or as fertilizer for the fertilization of soils with phosphorus deficiencies. 
Table 3

BIOACCUMULATION OF TOTAL PHOSPHORUS IN PLANTS EXPRESSED IN G/KG D.M.

\begin{tabular}{|c|c|c|c|}
\hline \multirow{2}{*}{ Experimental variants } & \multicolumn{3}{|c|}{ Temperature 25 $^{\circ} \mathbf{C}$} \\
\cline { 2 - 4 } & $\mathbf{0 ~ h}$ & $\mathbf{7 2 ~ h ~}^{\mathbf{1 2 0}} \mathbf{~ h}$ \\
\hline TP 4 & 3.60 & 11.2 & 10.2 \\
\hline TP 6 & 3.60 & 13.8 & 14.9 \\
\hline TP 8 & 3.60 & 14.6 & 15.3 \\
\hline TP 10 & 3.60 & 15.1 & 15.7 \\
\hline
\end{tabular}

The phosphorus bioaccumulation factor $(\mathrm{BCF})$ in plants was calculated for all three temperature and TP experimental sets for 24 and 72 hours (figures 5, 6 and 7). A higher BCF value suggested a greater phytoaccumulation capability.

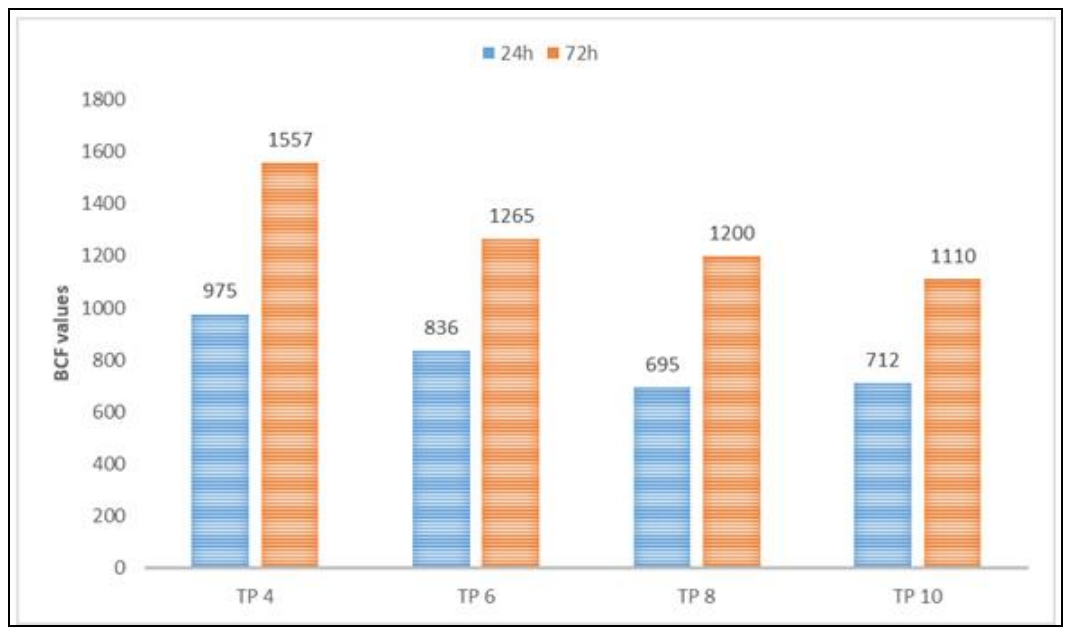

Fig. 5. Variation of $\mathrm{BCF}$ at $20^{\circ} \mathrm{C}$

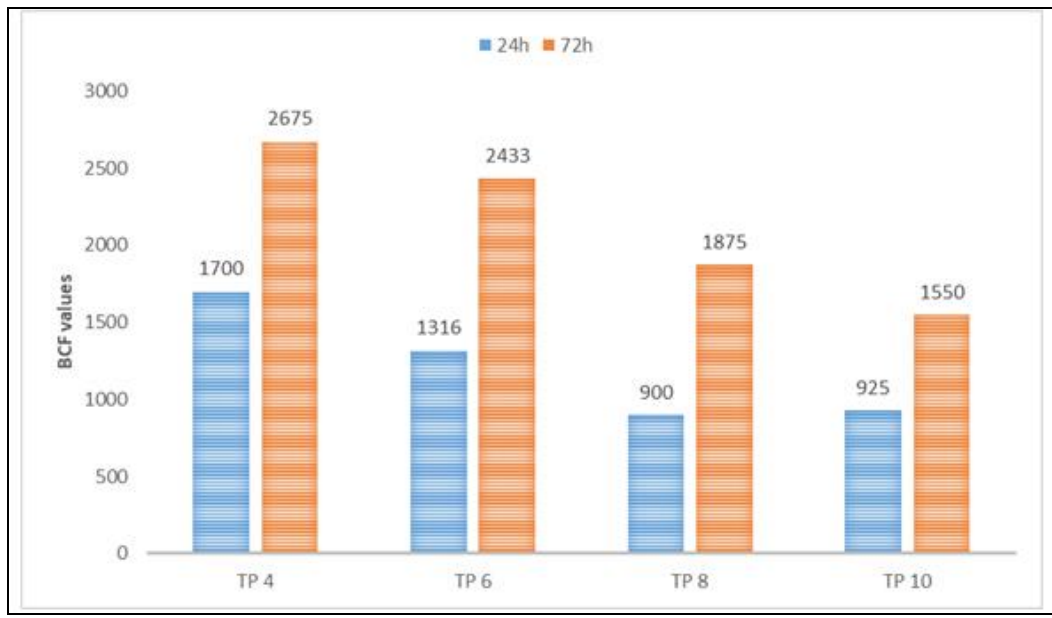

Fig. 6. Variation of $\mathrm{BCF}$ at $25^{\circ} \mathrm{C}$

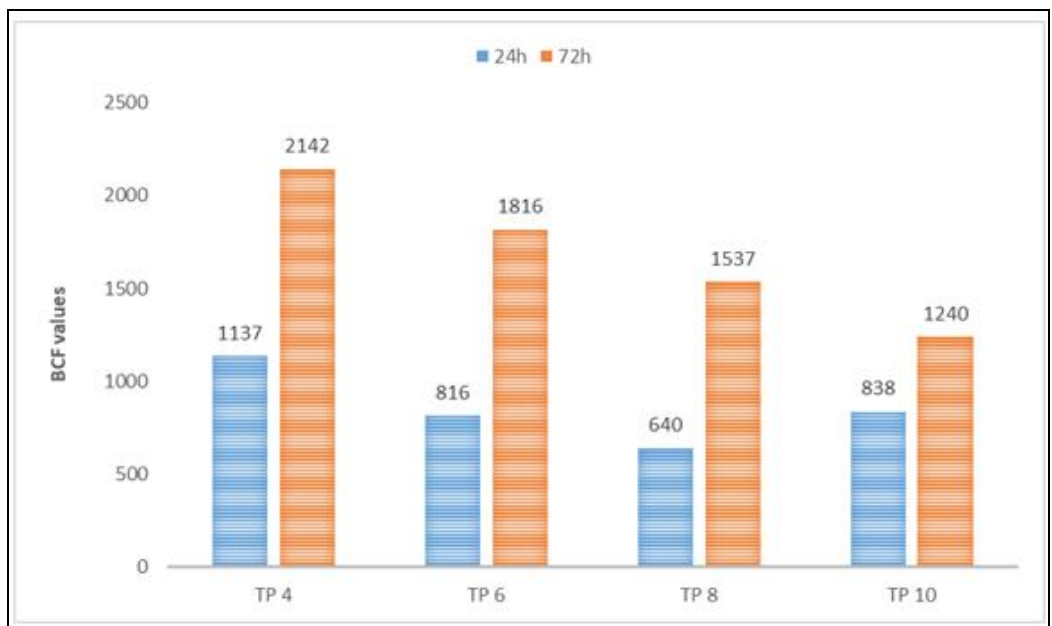


The BCF showed that highest values were recorded after 72 hours in all experimental variants at all preset temperatures. In addition, the factor values were inversely proportional to the total amount of phosphorus present in water at baseline, with a maximum around $4 \mathrm{mg} / \mathrm{L}$ and $6 \mathrm{mg} / \mathrm{L}$ phosphorus, which means that the values over $6 \mathrm{mg} / \mathrm{L} \mathrm{of}$ phosphorus in water inhibits its accumulation in the plant body, this being most clearly observed at $25^{\circ} \mathrm{C}$.

\section{Conclusions}

This study demonstrated the ability of the Lemna minor L. plant to accumulate total phosphorus from synthetic water. The degree of TP bioaccumulation was influenced by the TP initial concentration, temperature and incubation time. The best results for the removal of phosphorus from water were obtained at the temperature of $25^{\circ} \mathrm{C}$ in the experimental variants TP 4 and TP 6 with a percentage decrease of the organic substance in the water of 80 and $88.5 \%$ respectively, and the maximum quantities of phosphorus accumulated in the plant body were around $15 \mathrm{~g} / \mathrm{kg} \mathrm{d} . \mathrm{m}$. As mentioned above, the speed of bioaccumulation processes is maximum around the temperature of $25^{\circ} \mathrm{C}$, and the optimal experimental time is 72 hours when these processes are at high intensity.

A general conclusion of this study is that this plant can be successfully used in the removal of total phosphorus from water, due to the high absorption capacity of this pollutant, its rapid development, and the facile with which it can be harvested and renewed.

Future study will be developed to emphasis the modifications at the transcriptional and translational level when expose L. minor L. at various stressor such as chemicals and high temperature.

Acknowledgements: The present research was financially supported by the Romanian National "Nucleu” Program, contract no. 20 N/2019 ((Project code PN 19040201 ).

\section{References}

1. NEIDONI, D.G., NICORESCU, V., ANDRES, L., IHOS, M., DRAGALINA, M., IORDACHE, I., SIMINIC, I., NEGREA, S.C., DIACONU, L.A., The $24^{\text {th }}$ International Symposium on Analytical and Environmental Problems, 2018, p. 174.

2. Lu, B., Xu, Z., Li, J., Chai, X., Ecol. Eng., 110, 2018, p. 18.

3. LIU, C., DAI, Z., SUN, H., J. Environ. Manage, 187, 2017, p. 497.

4. NEIDONI, D.G., NICORESCU, V., ANDRES, L., IHOS, M., LEHR, C.B., International Symposium "The environment and the industry", SIMI 2018, Book of abstracts, 2018, p. 78.

5. CESCHINA, S., SGAMBATO, V., ELLWOOD, N. T. W., ZUCCARELLO, V., Environ. Exp. Bot., 162, 2019 , p. 67.

6. BONIARDI, N., VATTA,G., ROTA, R., NANO, G., CARRA, S., The Chem. Eng. J., 54, 1994, p. 41.

7. SUDIARTOA, S. I. A., RENGGAMANA, A., CHOI, H. L., J. Environ. Manage., 231, 2019, p. 763.

8. NEIDONI, D. G., NICORESCU, V., ANDRES, L., IHOS, M., LEHR, C. B., Rev. Chim. (Bucharest), 69, no. 11, 2018 , p. 3253.

9. MURADOV, N., TAHA, M., MIRANDA, A.F., KADALI, K., GUJAR, A., ROCHFORT, S., STEVENSON, T., BALL, A.S., MOURADOV, A., Biotechnol. Biofuels, 7, no.1, 2014, p. 30.

10. ASFAW, M. D., KASSA, S. M., LUNGU, E. M., BEWKET, W., Ecol. Modell, 406, 2019, p. 50.

11. STOICA, C., VASILE, G.G., BANCIU, A., NICULESCU, D., LUCACIU, I., LAZAR, M.N., Rev. Chim. (Bucharest), 68, no. 8, 2017, p. 1744.

12. SAVAGE, C., LEAVITT, P.R., ELMGREN, R., Baltic Sea. Limnol. Oceanogr., 55, 2010, p. 1033.

13. LOBIUC, A., OLARU, S., HANCU, E.I., COSTICA, N., FORTUNA, M.E., ZAMFIRACHE, M.M., CONSTANTINESCU, G., Rev.Chim. (Bucharest), 69, no. 7, 2018, p. 1628.

14. DU, C., WANG, Q., LI, Y., LYU, H., ZHU, L., ZHENG, Z., WEN, S., LIU, G., GUO, Y., Int. J. Appl. Earth Obs. Geoinformation, 71, 2018, p. 29.

15. MARCU, E., DEAK, G., CIOBOTARU, I.E., IVANOV, A.A., IONESCU, P., TOCIU, C., DIACU, E., Rev.Chim. (Bucharest), 68, no. 11, 2017, p. 2492.

16. ROMAN, M.D., MARE, R., HADAREAN, A., International Symposium “The environment and the industry", SIMI 2018, Proceedings Book, 2018 , p. 354.

17. IATROU, E.I., STASINAKIS, A.S., ALOUPI, M., Ecol. Eng., 84, 2015, p. 632.

18. XIAO, Y., FANG, Y., JIN, Y., ZHANG, G., ZHAO, H., Ind. Crop Prod., 48, 2013, p. 183.

Manuscript received: 31.07 .2019 
